Jacek Sierak*

\title{
PROGRAMOWANIE FINANSOWANIA KOMUNALNYCH PROJEKTÓW INWESTYCYJNYCH W NOWEJ PERSPEKTYWIE FINANSOWEJ UE 2014-2020
}

\section{Wprowadzenie}

Inwestycje komunalne stanowią jeden z najważniejszych czynników rozwoju lokalnego. Ich realizacja warunkuje poprawę jakości świadczenia usług dla mieszkańców oraz tworzy warunki rozwoju lokalnej gospodarki. W unijnej perspektywie finansowej 2014-2020 znaczna część środków będzie przeznaczona na finansowanie projektów inwestycyjnych związanych $\mathrm{z}$ krajowymi i regionalnymi programami operacyjnymi. Ich beneficjentem w istotnej części będą jednostki samorządu terytorialnego (JST). W procesie pozyskiwania dotacji unijnych bardzo duże znaczenie będą miały dwa elementy: umiejętne przygotowanie projektów inwestycyjnych oraz zapewnienie wkładu własnego $\mathrm{w}$ finansowanie inwestycji.

Wydatki inwestycyjne JST finansowane są z trzech zasadniczych źródeł: nadwyżki operacyjnej, przychodów o charakterze zwrotnym (kredyt, pożyczka, emisja dłużnych papierów wartościowych) oraz dochodów majątkowych, do których - obok środków na inwestycje z UE - należą dotacje celowe na dofinansowanie kosztów realizacji inwestycji, dochody ze sprzedaży mienia oraz przekształcenia prawa użytkowania wieczystego w prawo własności. Możliwość absorpcji środków unijnych będzie w dużym stopniu zależeć od zdolności do wygenerowania korzystnej tendencji kształtowania się nadwyżki operacyjnej, (różnica między dochodami bieżącymi a wydatkami bieżącymi) oraz pozyskiwania w odpowiednim czasie i w odpowiedniej wysokości środków pożyczkowych.

$\mathrm{W}$ ostatnich latach, $\mathrm{z}$ różnych przyczyn, własny potencjał finansowy jednostek samorządu terytorialnego ulegał ograniczeniu. $W$ takich warunkach pełne wykorzystanie przez JST szansy rozwoju związanej z możliwością dofinansowywania

* Uczelnia Łazarskiego, Wydział Ekonomii i Zarządzania. 
projektów ze środków Unii Europejskiej wymagać będzie pozyskania zewnętrznych źródeł finansowania.

Celem opracowania jest wykazanie uwarunkowań i zasad programowania komunalnych projektów inwestycyjnych w nowej perspektywie programowania UE, wskazanie źródeł ich finansowania oraz kierunków działań władz lokalnych, które przyczynią się do pozyskiwania funduszy unijnych.

\section{Istota i cechy inwestycji komunalnych}

Inwestowanie jest jednym z podstawowych rodzajów działalności w obszarze gospodarowania. Wywiera ono znaczący wpływ na tempo i kierunki rozwoju społecznego oraz gospodarczego. Zdecydowana większość działalności inwestycyjnej jednostek samorządu terytorialnego alokowana jest w rozwój infrastruktury. W definicjach infrastruktura to zespół urządzeń, a także inwestycji stwarzających podstawy dla właściwego funkcjonowania i rozwoju gospodarki na danym terenie oraz zapewniających odpowiednie warunki bytu ludności i możliwości ich poprawy ${ }^{1}$. Infrastruktura komunalna stanowi tę część infrastruktury, która poprzez urządzenia i zakłady działające w określonych systemach zaspokaja codzienne, powszechne potrzeby ludności oraz podmiotów gospodarczych znajdujących się na terenie danej jednostki samorządu terytorialnego ${ }^{2}$. Do infrastruktury komunalnej zalicza się: wodociągi i kanalizację, oczyszczalnie ścieków, drogi lokalne i komunikację miejską, oświetlenie ulic, urządzenia oczyszczania miast i wysypiska śmieci, sieci ciepłownicze, gazownicze i energetyczne, infrastrukturę społeczną.

Zapotrzebowanie na projekty inwestycyjne infrastruktury komunalnej zależy w dużym stopniu od wielkości i charakteru jednostki terytorialnej. Związany jest z tym bezpośrednio poziom kosztów realizacji zadań, tak w ujęciu ogółem, jak i w wymiarze jednostkowym. Bardziej efektywna jest budowa urządzeń, obiektów czy sieci infrastruktury w obrębie zwartej i przestrzennie uporządkowanej zabudowy mieszkalnej, gdzie duża liczba odbiorców na niewielkim obszarze ułatwia jej instalację i w przyszłości zapewnia lepsze wykorzystanie oraz wyższe przychody z opłat za jej użytkowanie, niż na terenach o rozproszonej zabudowie i niskiej liczbie użytkowników, gdzie koszty jednostkowe stają się bardzo wysokie.

1 Zob. M. Sadowy, Infrastruktura komunalna jako czynnik rozwoju miast polskich, SGPiS, Warszawa 1988, s. 20.

2 A. Ginsbert-Gebert, Zarys polityki komunalnej, SGPiS, Warszawa 1977, s. 38. 
Wśród cech infrastruktury komunalnej w istotny sposób wpływających na koszty realizacji zadań, a tym samym wyznaczających zapotrzebowanie na określone źródła finansowania, należy wymienić:

- liniowość urządzeń technicznych (umożliwia pokonywanie odległości),

- długowieczność użytkowania urządzeń,

- niepodzielność,

- kapitałochłonność (wysokie koszty inwestycji i eksploatacji), immobilność (trwale związanie z terenem),

- terenochłonność,

- skokowy sposób powstawania kosztów - koszty związane z rozwojem infrastruktury nie powiększają się w sposób ciągły, ale co pewien okres ${ }^{3}$.

Jednostki terytorialne rozwijają się progowo, co ma istotne znaczenie dla efektywności inwestycji i wielkości nakładów koniecznych na ich finansowanie. Według teorii B. Malisza ${ }^{4}$ progi rozwoju mogą mieć różnorodny charakter ${ }^{5}$ :

- progów przestrzennych, ograniczających od zewnątrz możliwości przestrzennego rozwoju miast i regionów (np. ograniczenia rozbudowy sieci kanalizacyjnej ze względu na ukształtowanie terenu),

- progów terenowych strukturalnych, polegających na tym, że rozwój miasta powoduje konieczność zmian struktury istniejącego zagospodarowania i użytkowania terenów (np. potrzeba przebudowy układu komunikacyjnego, który nie wystarczyłby do obsłużenia miasta większego),

- progów ilościowych, ograniczających nie zabudowę poszczególnych terenów, lecz miasta jako całości (np. ograniczona wydolność ujęć wodnych, oczyszczalni ścieków itp. urządzeń ogranicza rozwój miasta czy regionu i wymaga ich rozbudowy) ${ }^{6}$. Przy rozbudowie infrastruktury powinno się uwzględniać przyszłe potrzeby i w miarę możliwości antycypować przyszłe zapotrzebowanie na poszczególne usługi infrastrukturalne. Przekroczenie każdego progu wymaga alokacji wysokich nakładów finansowych. Dlatego pokonywanie kolejnych progów należy umiejętnie rozkładać w czasie ${ }^{7}$. Zarządzając procesami rozwoju miast i regionów, powinno się hamować rozwój w okresie przedprogowym i przyspieszać go po przekroczeniu progu.

3 J. Leśniak, Planowanie przestrzenne, PWN, Warszawa 1985, s. 137-139.

4 Zob. B. Malisz, J. Żurkowski, Metoda analizy progowej, PWN, Warszawa 1971.

5 Ibidem.

6 J. Regulski, Ekonomika miasta, PWE, Warszawa 1982, s. 156-157.

7 M. Sadowy, Elementy teorii i polityki infrastruktury, w: Gospodarka samorzadu terytorialnego cz. II, Oficyna Wydawnicza SGH, Warszawa 1995, s. 92. 
Budowa obiektów infrastruktury wymaga wysokich nakładów kapitałowych. Ich cechą charakterystyczną są wysokie koszty jednostkowe oraz znaczący udział kosztów stałych w ogólnej strukturze wydatków.

Inwestycje komunalne mają charakter ciągły. Dlatego należy realizować je w sposób planowy, uwzględniając zgłaszane lokalnie potrzeby rozwojowe. Przeszacowanie popytu (często popełniany błąd) może prowadzić do zbyt optymistycznego planowania przychodów generowanych przez projekt w fazie jego eksploatacji. Stąd też ważnym elementem przygotowania komunalnych projektów inwestycyjnych powinna być identyfikacja rodzajów potencjalnego ryzyka oraz analiza wrażliwości.

Istotną cechą inwestycji komunalnych jest ich prorozwojowy charakter. Rozwój infrastruktury prowadzi do wzrostu atrakcyjności danego terenu pod względem turystycznym, edukacyjnym, inwestycyjnym itd. ${ }^{8}$. Z kolei niedorozwój infrastruktury stanowi istotną barierę rozwojową, szczególnie dla wsi i małych miast.

Planując rozbudowę infrastruktury, należy mieć na uwadze substytucyjność i komplementarność jej elementów. Komplementarność to wzajemne uzupełnianie się poszczególnych gałęzi infrastruktury, substytucyjność zaś oznacza możliwość wyboru pomiędzy różnymi sposobami zaspokojenia tej samej potrzeby. Zależności te stawiają przed władzami samorządowymi zadanie kompleksowego programowania procesów rozwoju sieci, urządzeń i obiektów infrastruktury.

Skuteczne i efektywne inwestowanie wymaga umiejętnego przygotowania projektów. Źle przygotowane inwestycje mogą w przyszłości negatywnie wpływać na sytuację finansową JST. Dlatego też, z uwagi na długotrwały i kosztowny proces realizacji komunalnych inwestycji infrastrukturalnych, władze samorządowe powinny umiejętnie zarządzać procesami ich przygotowania i realizacji. Poszczególne projekty powinny być spójne i dostosowane do możliwości finansowych budżetu, zwłaszcza że jednostka samorządu terytorialnego jest nie tylko inwestorem, ale zazwyczaj także późniejszym użytkownikiem wybudowanej infrastruktury. Stąd, programując proces inwestycyjny, należy mieć na uwadze zarówno koszty budowy, jak i późniejsze koszty funkcjonowania. Zarządzając strategicznie, organy samorządowe powinny uchwalać realne, tzn. możliwe do wykonania w określonym przedziale czasowym, strategie rozwoju i wieloletnie programy inwestycyjne. Podejmowane decyzje inwestycyjne powinny opierać się na rachunku efektywności kosztowej i ekonomicznej. Zsumowane dodatnie efekty zewnętrzne powinny być tu większe od ponoszonych kosztów zewnętrznych (uwzględniając nie tylko bezpośrednie wydatki inwestycyjne, ale także koszty społeczne i ekologiczne).

8 K. Jarosiński, Finansowanie inwestycji komunalnych $w$ Polsce $w$ warunkach samorządności lokalnej, Oficyna Wydawnicza SGH, Warszawa 2003, s. 116-118. 
Podsumowując tę część rozważań, należy raz jeszcze wskazać na typowe cechy komunalnych projektów infrastrukturalnych w kontekście ich finansowania. Są nimi: kapitałochłonność inwestycji i nieodwracalność nakładów, długi cykl życia projektu oraz konieczność zastosowania wielu źródeł finansowania.

\section{Podstawowe założenia programowania nowej perspektywy 2014-2020}

W nowym okresie programowania 2014-2020 głównym kierunkiem dofinansowania inwestycji JST pozostanie infrastruktura, zmienią się natomiast preferencje finansowania inwestycji. Zdecydowanie większy nacisk położony zostanie na interwencje zintegrowane. W Polsce rolę tę pełnią zintegrowane inwestycje terytorialne ${ }^{9}$ jako instrumenty rozwoju, w ramach regionalnych programów operacyjnych na terenie miast będących siedzibą władz samorządu województwa oraz innych miast i obszarów powiązanych z nimi funkcjonalnie. Założenia te powodują, że w procedurze oceny wniosków aplikacyjnych wyżej oceniane będą inwestycje o zasięgu oddziaływania wykraczającym poza teren jednej gminy lub jednego powiatu, łączące w sobie różne elementy infrastruktury, mające charakter synergiczny oraz tworzące jak najwięcej nowych miejsc pracy.

W latach 2014-2020 środki unijne zostaną przeznaczone głównie na inwestycje długookresowe, czyli nastawione na długotrwały i zrównoważony rozwój, konkurencyjność, innowacyjność gospodarki oraz stworzenie jeszcze bardziej kreatywnego społeczeństwa. Część środków zaangażowanych zostanie na wsparcie w zakresie czynników wzrostu gospodarczego jako przeciwdziałanie negatywnym następstwom kryzysu finansowo-ekonomicznego, w tym niwelujących negatywne następstwa wahań cyklu koniunkturalnego.

W nowym okresie programowania większe niż w latach wcześniejszych znaczenie przypisuje się szeroko rozumianej innowacyjności i przedsiębiorczości. Rekomendowane jest nawiązanie i ciągłe wzmacnianie współpracy władz samorządowych z lokalnymi i regionalnymi środowiskami przedsiębiorców oraz środowiskami naukowo-badawczymi, w tym tworzenie warunków dla inwestorów planujących uruchomienie nowoczesnych ośrodków naukowo-badawczych, które wspomagałyby lokalną i regionalną gospodarkę.

\footnotetext{
9 W Polsce wprowadza je ustawa o zasadach realizacji programów w zakresie polityki spójności finansowanych w perspektywie finansowej 2014-2020, Dz. U. 2014, poz. 1146.
} 
W okresie 2014-2020 istotną rangę będą miały również inwestycje prośrodowiskowe, w dużym stopniu ukierunkowane na odnawialne źródła energii. $\mathrm{W}$ obszarze gospodarki niskoemisyjnej przewidziane jest wsparcie dla termomodernizacji budynków, wykorzystania biomasy, zwiększenie efektywności energetycznej sektora MSP, a także budowa instalacji OZE (o niewielkiej mocy). W tym zakresie rekomendowane jest opracowywanie planów gospodarki niskoemisyjnej, przygotowywanie i aktualizowanie przez gminę audytów energetycznych obiektów publicznych, a także eliminowanie nieekologicznych źródeł zasilania w ciepło w budynkach mieszkalnych.

Jednym z priorytetów programowania perspektywy 2014-2020 jest tworzenie cyfrowych fundamentów dla społeczno-gospodarczego rozwoju kraju. Preferowane $\mathrm{w}$ tym zakresie przedsięwzięcia to: szeroki dostęp do szybkiego internetu, efektywne i przyjazne użytkownikom e-usługi publiczne oraz stale rosnący poziom kompetencji cyfrowych społeczeństwa. Technologie cyfrowe powinny stawać się katalizatorem innowacyjności zarówno w sektorze prywatnym, jak i publicznym.

Od wielu lat władze UE duże znaczenie nadają inwestycjom w kapitał ludzki. Celem tych przedsięwzięć jest zwiększenie zatrudnienia, wzrost spójności społecznej, poprawa funkcjonowania administracji publicznej. Wśród tych zamierzeń wymienia się także efektywne wdrożenie reform systemów i struktur w wybranych obszarach polityki publicznej, istotnych z punktu widzenia Strategii Europa 2020 i programów krajowych.

Podobnie jak w poprzedniej perspektywie finansowej, wspierane będą działania mające na celu poprawę pozycji konkurencyjnej Polski Wschodniej. Mają one prowadzić do wzmocnienia rozwoju gospodarczego, w tym podniesienia poziomu innowacyjności gospodarki oraz rozwoju rynków pracy w makroregionie.

Jedno z podstawowych założeń programowych Komisji Europejskiej na nową perspektywę finansową to wzmocnione planowanie strategiczne. Jego istotą jest zwiększenie roli nowoczesnych instrumentów finansowych - rozszerzenie ich zakresu oraz elastyczności i efektywności zastosowania. Mają one stanowić skuteczną alternatywę lub środek uzupełniający tradycyjne wsparcie dotacyjne.

Władze lokalne, przygotowując projekty, powinny wykorzystywać instrumenty zarządzania strategicznego, takie jak strategie rozwoju, wieloletnie plany inwestycyjne i finansowe, programy rewitalizacji, instrumenty planowania przestrzennego. Projekty inwestycyjne powinny być konsultowane oraz w efekcie zintegrowane z operacyjnymi i strategicznymi zamierzeniami przyszłych potencjalnych partnerów (czyli innych samorządów, przedsiębiorców, organizacji non-profit oraz sfery badawczo-naukowej). Kryterium wyboru jest tu obiektywna ocena ich ekonomicznej efektywności oraz przyczynianie się do realizacji przyjętych celów operacyjnych i strategicznych. 
Z doświadczeń perspektywy 2007-2013 wynika, że niejednokrotnie dochodziło do sytuacji, gdy niestosowanie metod strategicznego zarządzania finansami było przyczyną problemów we współfinansowaniu projektów unijnych, a nawet prowadziło do zachwiania bądź utraty płynności finansowej JST. W związku z tym w nowej perspektywie podkreśla się konieczność stosowania instrumentów wieloletniego planowania finansowego, mających na celu wykazanie ekonomicznej zdolności beneficjenta do współfinansowania projektu.

\section{Przygotowanie projektów komunalnych do współfinansowania dotacjami unijnymi}

Przygotowanie projektu współfinansowanego dotacjami unijnymi wymaga przeprowadzenia wielu analiz, wykazujących instytucjonalne, techniczno-technologiczne, finansowo-ekonomiczne oraz środowiskowe uwarunkowania jego realizacji. Zarządzając projektami unijnymi, należy uwzględniać wymogi określone w unijnych i krajowych dokumentach programowych.

Szczegółowe wskazania odnoszące się do metodologii prowadzenia analizy ekonomicznej i finansowej, jak również analizy ryzyka, zawarto w rozporządzeniu wykonawczym Komisji (UE) nr 2015/207 z dnia 20 stycznia 2015 r. ${ }^{10}$. Zasady uszczegóławiające zamieszczono w podręczniku Guide to cost-benefit Analysis of Investment project. Economic appraisal tool for Cohesian Policy 2014-202011. Wprawdzie wymienione powyżej dokumenty zostały przygotowane dla oceny tzw. dużych projektów, nie ma jednak przeciwwskazań, by stosować je także do innych przedsięwzięć inwestycyjnych. Strona polska ze swojej strony opracowała Wytyczne Ministra Infrastruktury i Rozwoju w zakresie zagadnień związanych z przygotowaniem projektów inwestycyjnych, w tym generujących dochód i projektów hybrydowych. Uwzględniono w nich zarówno przepisy obowiązującego prawodawstwa europejskiego, zalecenia europejskie o charakterze metodologicznym, jak również doświadczenia krajowe wynikające z realizacji projektów w okresie 2007-2013.

W latach 2014-2020 na realizację polityki spójności w Polsce przyznano kwotę 82,5 mld EUR, w tym ok. 76,9 mld EUR dostępną w programach operacyjnych ${ }^{12}$. W nowym okresie programowania samorządy województw będą zarządzać około

\footnotetext{
${ }^{10} \mathrm{http}: / /$ eur-lex.europa.eu/legal-content/PL/TXT/PDF/?uri=OJ:L:2015:038: FULL\&from=EN

$11 \mathrm{http} / / /$ ec.europa.eu/regional_policy/sources/docgener/studies/pdf/cba_guide.pdf

12 Programowanie perspektywy finansowej 2014-2020 - Umowa Partnerstwa, Ministerstwo Infrastruktury i Rozwoju, Warszawa 2014, s. 159.
} 
$40 \%$ funduszy polityki spójności, co stanowi kwotę 31,28 mld EUR. Kierowane przez zarządy województw regionalne programy operacyjne będą dwufunduszowe, tj. finansowane ze środków Europejskiego Funduszu Rozwoju Regionalnego i Europejskiego Funduszu Społecznego (to nowość w porównaniu z perspektywą 2007-2013).

Zasada dodatkowości polityki regionalnej określa, że dotacje unijne kierowane z funduszy strukturalnych w finansowaniu projektów nie zastępują, a uzupełniają krajowe środki publiczne ${ }^{13}$. Pozyskanie wsparcia unijnego na realizację zadań mających na celu niwelowanie występującej lokalnie i regionalnie luki infrastrukturalnej zależeć będzie od zapewnienia pożądanego poziomu wkładu własnego. Jego wysokość w każdym wypadku wynika $\mathrm{z}$ ustaleń umowy o dofinansowanie projektu.

W budżetowaniu projektu ważnym elementem jest prawidłowe zaplanowanie kosztów kwalifikowanych projektu. Dla każdego z programów opracowane są wytyczne realizacji projektów, w ramach których określony jest katalog kosztów niekwalifikowanych, czyli takich, których nie można umieścić w budżecie jako kosztów podlegających refinansowaniu. Kwalifikowalność wydatków odnosi się zawsze do określonego przedziału czasowego, ustalonego w warunkach konkursu. Finansowanie projektów unijnych opiera się także na zasadzie refundacji kosztów. Zasada ta polega na tym, że ustalona część kosztów objętych dotacją z UE musi być wyprzedzająco pokryta przez beneficjenta, a dopiero po zrealizowaniu i rozliczeniu projektu (lub transzy) podlegają one refundacji. W latach 2014-2020 w projektach komunalnych dofinansowanych dotacjami unijnymi kosztem kwalifikowanym pozostaje podatek VAT, co dla JST oznacza możliwości jego refundacji. To korzystna sytuacja, dająca możliwość obniżenia wielkości angażowanych w projekt własnych środków budżetowych.

Wysoki udział kosztów niekwalifikowanych ma niekorzystny wpływ na strukturę finansowania projektu. W całości obciążają one budżet beneficjenta, tym samym obniżony zostaje poziom dofinansowania projektu dotacją unijną. Im wyższy jest udział kosztów kwalifikowanych w kosztach ogółem, tym sytuacja beneficjenta jest korzystniejsza. $\mathrm{W}$ takiej sytuacji wymagane jest bowiem niższe zaangażowanie własnych środków budżetowych. Wzajemne proporcje pomiędzy obydwiema grupami kosztów mają więc znaczenie dla określenia właściwego zapotrzebowania na poszczególne źródła finansowania projektu w części stanowiącej wkład własny.

W latach 2007-2013 przyjmowane często przez władze samorządowe założenie uzyskania maksymalnego (85\%) wsparcia unijnego dla każdego wnioskowanego projektu okazywało się zbyt optymistyczne. Rzeczywisty średni poziom dofinansowania był bowiem znacznie niższy. Analiza projektów zamieszonych w bazie SIMIK

${ }^{13}$ I. Pietrzyk, Polityka regionalna Unii Europejskiej i regiony w państwach członkowskich, Wydawnictwo Naukowe PWN, Warszawa 2004, s. 153-189. 
wykazała następujący faktyczny poziom ich dofinansowania środkami unijnymi: dla gmin $-58,35 \%$, dla powiatów $-64,68 \%$, dla województw $-70,26 \%{ }^{14}$. Zbyt optymistyczne planowanie poziomu wsparcia może skutkować problemami w finansowaniu projektu w fazie jego realizacji i późniejszej eksploatacji.

Podobnie jak w okresie 2007-2013, dla projektów komunalnych wyodrębniono tzw. projekty inwestycyjne generujące dochód ${ }^{15}$. Obejmują one przedsięwzięcia, które przynoszą wpływy środków pieniężnych z bezpośrednich wpłat dokonywanych przez użytkowników za towary lub usługi zapewniane przez daną operację, w wysokości przewyższającej wszelkie związane z projektem koszty operacyjne i koszty odtworzenia wyposażenia poniesione w okresie realizacji oraz życia ekonomicznego projektu. Poziom dofinansowania dla takich inwestycji w nowej perspektywie określa się za pomocą nowego mechanizmu, opartego na tzw. zryczałtowanych procentowych stawkach dochodów lub też przy wykorzystaniu metody tzw. luki w finansowaniu.

\section{4. Źródła finansowania projektów w nowej perspektywie finansowej}

Podjęcie decyzji o realizacji inwestycji komunalnych, ze względu na ich specyficzne cechy, wymaga przygotowania wieloletniej strategii finansowania, obejmującej:

- wyznaczenie własnego potencjału finansowego JST, w tym potencjału inwestycyjnego,

- zapewnienie w budżecie kwot na finansowanie udziału własnego,

- racjonalny dobór zewnętrznych źródeł finansowania,

- monitoring zdolności kredytowej oraz wyznaczenie warunków utrzymania płynności finansowej.

Dokonując ogólnego podziału źródeł finansowania inwestycji komunalnych, wyróżnia się finansowanie własne i obce. Środki własne pochodzą z dochodów bieżących (np. opłaty i podatki lokalne, udziały w podatkach PIT i CIT, dochody jednostek budżetowych), z majątku komunalnego oraz wpłat gminnych spółek prawa handlowego. Zewnętrzne źródła finansowania pozyskiwane są w trzech formach, jako: środki bezzwrotne (subwencje, dotacje, dotacje unijne, darowizny), środki zwrotne

${ }_{14}$ Zob. J. Sierak, M. Bitner, A. Gałązka, Oszacowanie środków niezbędnych do zapewnienia krajowego wkładu publicznego do projektów realizowanych $w$ ramach średniookresowych ram finansowych 2014-2020, Wydawnictwo MIR, 2013

${ }^{15}$ Szczegóły Art. 61 Rozporządzenia Parlamentu Europejskiego i Rady (UE) nr 1303/2013 z dnia 17.12.2013. 
(pożyczki i kredyty komercyjne oraz preferencyjne, obligacje komunalne), finansowanie pozabudżetowe (leasing, factoring, umowy partnerskie PPP).

Każda $\mathrm{z}$ form finansowania ma swoje odrębne cechy i powinna być zastosowana w zależności od występujących uwarunkowań wewnętrznych (po stronie gminy) i zewnętrznych (po stronie źródła finansowania). Dobór źródeł finansowania projektu powinien zostać poprzedzony wnikliwą analizą kosztów i korzyści, uwzględniającą kryteria i cechy danego źródła finansowania oraz charakter, a także specyfikę zadania inwestycyjnego. Pod uwagę należy brać również możliwie szeroki zakres determinant o charakterze prawnym i organizacyjnym.

Podstawą budżetowania projektu komunalnego są własne środki budżetowe. Ich zasobność decyduje o możliwości zastosowania innych - uzupełniających - źródeł finansowania. Wysoki udział dochodów własnych w budżecie JST daje także podstawy do tworzenia wiarygodnych prognoz finansowych w różnych scenariuszach finansowania projektu. Zwiększa to bezpieczeństwo realizacji przedsięwzięcia inwestycyjnego.

Władze samorządowe, zarządzając finansami powinny dążyć do racjonalnej relacji pomiędzy poziomem dochodów i wydatków bieżących. Ma to swój wymiar w wielkości generowanej nadwyżki operacyjnej, która informuje, ile środków finansowych pozostaje w budżecie po pokryciu najważniejszych wydatków związanych z bieżącym funkcjonowaniem JST. Gminy, powiaty i województwa, które nie generują nadwyżki operacyjnej, a chcą zapewnić wkład własny do projektów inwestycyjnych zmuszone są sprzedać swój majątek albo sięgać po instrumenty rynku dłużnego. W dłuższym okresie polityka taka, jeśli prowadzona jest nieracjonalnie, może zagrażać płynności finansowej JST. Dlatego władze publiczne, planując realizację projektów inwestycyjnych, powinny dążyć do osiągania możliwie wysokich dochodów budżetowych oraz ciągłej racjonalizacji wydatków (zwłaszcza bieżących). Oczywiście samo istnienie nadwyżki operacyjnej nie przesądza o dobrej kondycji finansowej jednostki samorządowej. Kategoria ta nie obejmuje bowiem dochodów i wydatków majątkowych oraz przychodów i rozchodów. Dla właściwej oceny sytuacji finansowej JST należy przeprowadzić całościowy rachunek przepływów finansowych, którego efektem finalnym będzie wykazanie skumulowanego stanu gotówki na koniec każdego kolejnego roku budżetowego w okresie realizacji i eksploatacji projektu, przy założeniach określonego wariantu polityki finansowej.

Drugim ważnym miernikiem zdolności JST do pozyskiwania dotacji unijnych jest bieżący i prognozowany poziom ich indywidualnego wskaźnika zadłużenia. Jego zgodność z przepisami ustawy o finansach publicznych warunkuje możliwość sięgania po zwrotne źródła finansowania inwestycji. Przekroczenie wyznaczonego przepisami ustawy poziomu wskaźnika może stać się istotną barierą kształtowania budżetu projektów. 
Jak już wspomniano wyżej, dochody własne nie stanowią wystarczającego zasobu środków zapewniających pożądany poziom wkładu własnego. W tym celu władze publiczne podejmują decyzje mające na celu pozyskanie zewnętrznych źródeł finansowania projektów. W pierwszej kolejności poszukują dofinansowania bezzwrotnego. Ze środków krajowych największe znaczenie mają tu dotacje pozyskiwane z funduszy celowych, przede wszystkim z Narodowego i Wojewódzkich Funduszy Ochrony Środowiska na cele określone w ustawie o ochronie i kształtowaniu środowiska. Ważnym zadaniem NFOŚiGW jest również efektywne i sprawne wdrażanie środków z Unii Europejskiej, przeznaczonych w ramach programów operacyjnych na rozbudowę i modernizację infrastruktury ochrony środowiska.

Ze wszystkich zewnętrznych źródeł finansowania w praktyce finansowania komunalnych projektów inwestycyjnych największe znaczenie mają kredyty bankowe. Już pierwsze lata członkostwa Polski w Unii Europejskiej przyniosły szybki rozwój rynku kredytów strukturalnych. Widoczne to było zarówno w ich narastającej wartości, jak i w liczbie banków świadczących ten rodzaj usług. W wielu JST zaciągnięcie kredytu stanowiło warunek pozyskania dotacji unijnej, a tym samym realizacji planowanych projektów i programów inwestycyjnych.

W ostatnich kilku latach dynamika zadłużania się samorządów uległa spowolnieniu. Przyczyn jest kilka. W wyniku kryzysu finansowego i gospodarczego banki komercyjne zaostrzyły politykę kredytową, podniosły także wymagania dotyczące zabezpieczeń kredytowych. Samorządom dano możliwość zaliczkowego finansowania projektów oraz skierowano do nich preferencyjne oferty w ramach linii Banku Gospodarstwa Krajowego (BGK). W następstwie kryzysu pogorszyły się wyniki finansowe JST, co ograniczyło ich zdolność do zaciągania nowych zobowiązań dłużnych.

W perspektywie finansowej 2014-2020 należy spodziewać się dalszej współpracy banków i JST w finansowaniu projektów komunalnych. Występujący zakres potrzeb inwestycyjnych, w zestawieniu z możliwościami budżetowymi samorządów, wyznacza zapotrzebowanie na finansowanie zewnętrzne. W tym zakresie banki będą aktywnie uczestniczyły w finansowaniu wkładu własnego beneficjentów, kosztów niekwalifikowanych projektów oraz w udzielaniu kredytów obrotowych służących zapewnieniu płynności finansowej. Oczywiście, bank każdorazowo uzależnia przyznanie kredytu od zdolności kredytowej JST, rozumianej jako zdolność do spłaty zaciągniętego kredytu wraz z odsetkami w terminach określonych w umowie.

Wśród ofert banków kierowanych do samorządów na współfinansowanie projektów komunalnych występują kredyty oferowane na warunkach rynkowych oraz kredyty preferencyjne. W tej drugiej grupie wskazać można na kredyty inwestycyjne, których spłata częściowo może być finansowana przez instytucje zewnętrzne. Niektóre banki (liderem jest BOŚ) udzielają niskooprocentowanych kredytów proekologicznych. 
Ma to często miejsce we współpracy z Funduszami Ochrony Środowiska. Preferencje mogą przybierać różne postaci (oprocentowanie, termin, karencja) i są zazwyczaj uwarunkowane osiągnięciem zakładanego efektu realizacji projektu.

W szerokiej ofercie przygotowanej samorządom przez BGK znajdują się preferencyjne kredyty na finansowanie projektów inwestycyjnych związanych z rozwojem infrastruktury, w tym na Program Inwestycje Polskie. Preferowane kierunki to: energetyka i ciepłownictwo, transport i infrastruktura transportowa, wodociągi i kanalizacja, gospodarka odpadami, służba zdrowia, infrastruktura socjalna oraz związana $\mathrm{z}$ władzami lokalnymi i centralnymi. W ofercie BGK wyspecjalizowany charakter ma np. kredyt inwestycyjny na realizację projektu dofinansowanego ze środków z budżetu Unii Europejskiej, który może być wykorzystany na: finansowanie pomostowe, finansowanie kosztów kwalifikowanych projektu podlegających dofinansowaniu, kosztów kwalifikowanych nieobjętych dofinansowaniem oraz kosztów niekwalifikowanych. Oferowane są także kredyty ze środków Europejskiego Banku Inwestycyjnego na finansowanie rozwoju regionalnego oraz pożyczki z dofinansowaniem UE - w ramach Inicjatywy JESSICA - na wspólne europejskie wsparcie na rzecz trwałych inwestycji w obszarach miejskich.

Alternatywnym w stosunku do kredytów bankowych, zwrotnym źródłem finansowania są obligacje komunalne. Ich udział na rynku finansowania projektów komunalnych jest jednak znacznie niższy niż kredytów. Cele finansowania mogą być tu różnorodne i dotyczyć infrastruktury komunalnej (wodociągi, kanalizacja, budynki użyteczności publicznej, drogi, oświetlenie uliczne), ochrony środowiska (składowiska odpadów, oczyszczalnie ścieków), inwestycji infrastruktury społecznej (obiekty sportowe, oświatowe, kultura). Zaletą tego instrumentu jest możliwość kształtowania warunków emisji, w szczególności doboru terminów i wielkości spłaty zadłużenia w odniesieniu do bieżącej sytuacji finansowej JST. Szczególnym rodzajem obligacji komunalnych, występującym także na rynku polskim, są tak zwane obligacje przychodowe ${ }^{16}$. Ich podstawową zaletą jest możliwość ograniczenia odpowiedzialność emitenta (JST) do wysokości przychodów, jakie przyniesie finansowana $\mathrm{w}$ ten sposób inwestycja. Polskie miasta przeprowadzały także emisje euroobligacji.

Jak dotąd niewielkie znaczenie mają alternatywne źródła finansowania, takie jak leasing czy factoring. Mając na uwadze ograniczoność środków budżetowych i wysoki poziom zadłużenia wielu samorządów, a także zalecenia Komisji Europejskiej, można przypuszczać, że w nowej pespektywie finansowej zwiększy się rola

${ }^{16}$ Ustawa z dnia 29 czerwca 2000 r. o zmianie ustawy o obligacjach oraz niektórych innych ustaw, Dz. U. 2000, $\mathrm{nr} 60$, poz. 702 . 
partnerstwa publiczno-prywatnego, jako formy finansowania kapitałochłonnych inwestycji infrastrukturalnych.

\section{Podsumowanie}

Jednostki samorządu terytorialnego funkcjonują w warunkach występowania ilościowej i jakościowej luki infrastrukturalnej. Jej niwelowanie wymagać będzie jeszcze przez wiele lat alokacji wysokich nakładów inwestycyjnych. Nowy okres programowania UE, obejmujący perspektywę 2014-2020 tworzy warunki dalszego kształtowania procesów rozwoju lokalnego i regionalnego, oparte na wykorzystaniu funduszy unijnych. Kryterium ich pozyskania będzie dostosowanie projektów do zasad programowania ustalonych w dokumentach unijnych i krajowych. Konieczne będzie również zapewnienie wkładu własnego w finansowaniu przedsięwzięć inwestycyjnych. Podstawą tego będą własne środki budżetowe, uzupełnione o dotacje krajowe i instrumenty rynku dłużnego. Ważnym czynnikiem efektywnej absorpcji środków unijnych może być zastosowanie instrumentów inżynierii finansowej.

Jednostki samorządu terytorialnego, przygotowując projekty inwestycyjne, powinny stosować nowoczesne metody programowania oraz instrumenty zarządzania strategicznego. Działania podejmowane w tym zakresie mają być spójne, a podejmowane decyzje wzajemnie zintegrowane. Metody te powinny prowadzić do lepszego wykorzystania istniejącego lokalnie potencjału społeczno gospodarczego oraz racjonalnego kształtowania procesów rozwoju lokalnego i regionalnego.

\section{Bibliografia}

Ginsber-Gebert A., Zarys polityki komunalnej, SGPiS, Warszawa 1977.

Jarosiński K., Finansowanie inwestycji komunalnych w Polsce w warunkach samorządności lokalnej, Oficyna Wydawnicza SGH, Warszawa 2003.

Leśniak J., Planowanie przestrzenne, PWN, Warszawa 1985.

Malisz B., Żurkowski J., Metoda analizy progowej, PWN, Warszawa 1971.

Pietrzyk I., Polityka regionalna Unii Europejskiej i regiony w państwach członkowskich, Wydawnictwo Naukowe PWN, Warszawa 2004.

Regulski J., Ekonomika miasta, PWE, Warszawa 1982. 
Sadowy M., Elementy teorii i polityki infrastruktury, Gospodarka Samorzadu terytorialnego cz. II, Oficyna Wydawnicza SGH, Warszawa 1995.

Sierak J., Bitner M., Gałązka A., Oszacowanie środków niezbędnych do zapewnienia krajowego wkładu publicznego do projektów realizowanych w ramach średniookresowych ram finansowych 2014-2020, Wydawnictwo MIR, 2013.

\section{Financial Programming of Municipal Investment Projects in the EU's New Financial Perspective (2014-2020)}

According to the new EU financial perspective, a significant portion of funds will be allocated to fund municipal projects, whose beneficiaries include local government units. In the process of obtaining EU subsidies two elements will have great importance: investment projects and financial contribution to the investments. The paper focuses on the conditions of implementation of municipal investment projects in the new EU programming perspective, and on principles of project financing and the sources of funding.

Keywords: municipal projects financing, local government units, new EU programming perspective

\section{La programmation financière des projets d'investissement municipaux dans la nouvelle perspective financière de l'UE (2014-2020)}

Selon la nouvelle perspective financière de l'UE, une partie importante des fonds sera allouée pour financer des projets municipaux, dont les bénéficiaires comprennent des unités gouvernementales locales. Pour obtenir des subventions de l'UE deux éléments auront une grande importance: les projets d'investissement et la contribution financière aux investissements. Le document met l'accent sur les conditions de la mise en œuvre des projets d'investissement municipaux dans la nouvelle perspective de l'UE, et sur les principes du financement de ces projet et les sources de financement.

Mots-clés: le financement des projets municipaux, les unités gouvernementales locales, la nouvelle perspective de la programmation de l'UE 


\section{Программирование финансирования муниципальных инвестиционных проектов в финансовых рамках ЕС на 2014-2020 гг.}

В новой финансовой перспективе ЕС значительная часть средств будет направлена на финансирование муниципальных проектов, которых бенефициаром станут местные органы власти. В процессе получения субсидий ЕС большое значение будут иметь два элемента: умелая подготовка инвестиционных проектов и осуществление собственного вклада в финансирование проекта. В статье особое внимание уделяется условиям реализации муниципальных инвестиционных проектов в новой финансовой перспективе $\mathrm{EC}$, принципам и источникам финансирования проектов.

Ключевые слова: финансирование муниципальных проектов, органы местного самоуправления, новая финансовая перспектива ЕС 
